\title{
Factors influencing disease-induced mortality of Pacific oysters Crassostrea gigas
}

\author{
Bruno Petton ${ }^{1}$, Pierre Boudry ${ }^{2}$, Marianne Alunno-Brusciaa ${ }^{1}$, Fabrice Pernet ${ }^{2, *}$ \\ ${ }^{1}$ Ifremer, UMR LEMAR 6539 (UBO/CNRS/IRD/Ifremer), 11 presqu'île du Vivier, 29840 Argenton-en-Landunvez, France \\ ${ }^{2}$ Ifremer, UMR LEMAR 6539 (UBO/CNRS/IRD/Ifremer), Technopole de Brest-Iroise, BP 7029280 Plouzané, France
}

\begin{abstract}
Mortalities of oyster Crassostrea gigas seed associated with ostreid herpesvirus OsHV-1 $\mu$ Var have been observed in many oyster-producing countries since 2008. The present study, comprised of 4 complementary experiments, aimed to identify factors associated with disease-induced oyster mortality in order to propose mitigation strategies. Our first experiment compared survival of oysters from natural spatfall with others sampled from nurseries, after thermal elevation in the laboratory from $<14$ to $21^{\circ} \mathrm{C}$. A total of $60 \%$ of the tested wild seed batches $(\mathrm{n}=$ 51) were infected by OsHV-1, exhibited mortality and were able to transmit the disease to cohabited naïve oysters. Comparatively, only 1 out of the 32 tested batches sampled from nurseries presented similar characteristics. In a second experiment, we studied the effects that timing and duration of exposure to field conditions had on risk of infection and mortality in the laboratory at $21^{\circ} \mathrm{C}$. Naïve oysters deployed in the field during winter and spring, when seawater temperatures were $<14.7^{\circ} \mathrm{C}$, showed no mortality in the laboratory, and OsHV-1 DNA was not detected by PCR. However, in oysters transferred to the field, OsHV-1 was observed when seawater temperature reached $\sim 15.3^{\circ} \mathrm{C}$. Our third experiment showed that the odds of mortality decreased with age of oysters when facing the disease. Further, we observed that odds of disease mortality decreased with water renewal and increased with the biomass of neighbouring infected oysters under controlled conditions. Based on these findings, we propose mitigation strategies in terms of the regulation of oyster movements between sites, timing of seeding and spatial planning, taking into account seawater temperature and seed origin.
\end{abstract}

KEY WORDS: Epidemiology $\cdot$ Risk analyses $\cdot$ Shellfish farming $\cdot$ Virus OsHV-1 $\mu$ Var

\section{INTRODUCTION}

Since 2008, mass mortalities of juvenile Pacific oysters Crassostrea gigas have occurred at rearing sites along the coast of France when seawater temperature exceeds $16^{\circ} \mathrm{C}$ (Pernet et al. 2012, 2014b, Dégremont 2013, Petton et al. 2013). Mortality of oyster seed ( $<1 \mathrm{yr}$ ) ranges from 40 to $100 \%$, depending on locations and batches, whereas older animals are generally much less affected (Oden et al. 2011, Pernet et al. 2012, Dégremont et al. 2013). This represents the most serious crisis the French oyster industry has faced since the mass mortality of Crassostrea angulata in the late 1960 s, which lead to the intro-

\footnotetext{
*Corresponding author: fabrice.pernet@ifremer.fr
}

duction of C. gigas in the early 1970s (Grizel \& Heral 1991). Although Pacific oyster mortalities have mainly been reported in France during this period, there have also been several cases in the UK, Australia and New Zealand (EFSA 2010, Peeler et al. 2012, Bingham et al. 2013, Jenkins et al. 2013, Paul-Pont et al. 2013, Clegg et al. 2014), and more recently in Norway (S. Mortensen pers. comm.). Results of diagnostic tests indicate that recent mortality events are associated with the detection of a particular genotype of the ostreid herpesvirus 1, named $\mu$ Var (OsHV-1; Segarra et al. 2010, Jenkins et al. 2013).

Limited knowledge regarding risk factors of disease transmission and subsequent mortality has lim-

() The authors 2015. Open Access under Creative Commons by Attribution Licence. Use, distribution and reproduction are unrestricted. Authors and original publication must be credited. 
ited the development of specific protective measures for oyster farming. Additionally, unlike most other animal productions, disease curative treatments or vaccinations are not feasible in oysters (Renault 2011). As a result of the inherent dependence of the productive system on environmental hazards, oyster farmers regularly develop and conduct adaptation and risk integration strategies. Restrictions on the movements of livestock between production basins, spatial planning and density regulation in oyster beds are a few examples of farming practices implemented in response to mass mortality events (V. Le Bihan pers. comm.). In this context, additional mitigation measures are clearly needed to reduce the risks of disease transmission and mortality (Pernet et al. 2014a) in conjunction with selective breeding to improve disease resistance (Dégremont et al. 2010a).

The objective of the present study was to examine the effects of specific environmental and life-history parameters of oysters on disease susceptibility, transmission and subsequent mortality, in order to aid in mitigation strategies. To that end, 4 experiments were designed to test the effects of (1) rearing history of oyster seed, (2) timing and duration of exposure to the disease in the field, (3) age and size of oysters and (4) water renewal and biomass of infected animals on disease transmission and related mortalities in $C$. gigas. These experiments relied on (1) the production of standardised oyster seed under controlled conditions, (2) the use of this oyster seed for investigating the infection pressure in different environments and (3) the development of a protocol based on seawater temperature elevation in the laboratory to activate OsHV-1 in asymptomatic carriers.

The first question was addressed by investigating the effect of the origin of oysters (i.e. natural spatfall vs. nurseries) on disease transmission and mortality risk. In France, oysters originate either from natural spatfall collected along the Atlantic coast, or alternatively, from hatcheries and nurseries. In the field, oysters are unpredictably exposed to OsHV-1, whereas in hatcheries and nurseries they can be protected by means of prophylactic methods such as ultra-violet light (see details in Schikorski et al. 2011b) and seawater filtration $(<5 \mu \mathrm{m}$, Whittington et al. 2015). Here, we tested whether the sanitary status of oyster seed is influenced by its rearing history, and explored how this could be taken into account for building disease management scenarios.

The next question we addressed was to assess the effect of timing and duration of exposure to field conditions that would result in infection and mortality in a safe environment. This parameter was evaluated in winter, spring and summer as it could potentially reflect the seasonality of virus-host interactions (EFSA 2010, Oden et al. 2011, Pernet et al. 2012, Paul-Pont et al. 2014). It is likely that during the winter when seawater temperature is far below $16^{\circ} \mathrm{C}$, the risk of OsHV-1 $\mu$ Var transmission to healthy oysters is low (EFSA 2010, Oden et al. 2011, Pernet et al. 2012, 2014b, Dégremont 2013, Petton et al. 2013), so that oysters could be transferred from one location to another with an acceptable risk of disease transmission. This parameter might be useful for managing the movements of livestock among shellfish culture sites, which is a common practice in France in order to optimize growth (Goulletquer \& Le Moine 2002).

Thirdly, we tested the effect of age and/or size on disease susceptibility in oysters. Although several studies have reported that disease-induced mortality is lower in adults compared to other age groups (Oden et al. 2011, Peeler et al. 2012, Pernet et al. 2012, Dégremont et al. 2013, Paul-Pont et al. 2013, 2014), this generally reflects a mechanism whereby oysters that have survived a mortality event are naturally selected for resistance to that disease (Dégremont 2011, Peeler et al. 2012, Pernet et al. 2012, Dégremont et al. 2013). However, it has generally not been possible to disentangle the relative importance of age and prior OsHV-1 exposure. The effect of age and/or size on disease mortality in oysters was recently investigated by exposing healthy oysters at ages varying from 3 to 20 mo to field conditions between July 2009 and September 2011 in the Marennes-Oléron Bay (France), where mortalities were occurring seasonally (Dégremont 2013). In that study, both age and/or size of oysters were negatively correlated with final cumulative mortality. In contrast, in Thau lagoon (another oyster production area in France), oysters remained highly susceptible to pathogen-related mortality pressure during their first 2 yr (Pernet et al. 2012). The novelty of our work is that oysters of different ages were exposed to the same mortality event, contrary to previous studies where the timing of exposure and age and/or size of oysters were confounded.

Finally, the last question we addressed was to study the effect of water renewal and biomass of infected animals on disease mortality of oysters. Transmission of OsHV-1 within an oyster population occurs when susceptible hosts encounter infectious particles in the environment that have been shed by neighbouring infected individuals (Schikorski et al. 2011a, Petton et al. 2013, Pernet et al. 2014a,b). We hypothesized that disease-induced mortality risk would increase with the biomass of neighbouring infected 
oysters and decrease with water renewal, reflecting concentration and dilution effects of viral particles in seawater, respectively.

\section{MATERIALS AND METHODS}

\section{Animals}

Wild individuals were collected in Fouras (Marennes-Oléron, France; $46^{\circ} 0^{\prime} 43^{\prime \prime} \mathrm{N}, 1^{\circ} 7^{\prime} 3^{\prime \prime} \mathrm{W}$ ) in August 2008 and placed in mesh bags in February 2009 for transport to Paimpol (northern Brittany, France; $48^{\circ} 48^{\prime} 25^{\prime \prime} \mathrm{N}, 3^{\circ} 0^{\prime} 23^{\prime \prime} \mathrm{W}$ ) until February 2010. The animals were then moved to a grow-out farm located at Aber Benoît, (northern Brittany, France; $48^{\circ} 34^{\prime} 30^{\prime \prime} \mathrm{N}, 4^{\circ} 36^{\prime} 18^{\prime \prime} \mathrm{W}$ ) until being used as broodstock. These animals were exposed to the disease during the spring 2009 and suffered ca. $75 \%$ mortality (Petton et al. 2013).

Between March 2010 and April 2011, 10 batches of 40 adult oysters each were transferred every $6 \mathrm{wk}$ to the Ifremer facilities in Argenton (Brittany, France; $48^{\circ} 31^{\prime} 16^{\prime \prime} \mathrm{N}, 4^{\circ} 46^{\prime} 2^{\prime \prime} \mathrm{W}$ ) for a conditioning period of 32 to $45 \mathrm{~d}$ (Table 1). These animals were held in $500 \mathrm{l}$ flow-through tanks with seawater held at a constant temperature of $17^{\circ} \mathrm{C}$ and enriched with a phytoplankton mixture. Seawater was treated with UV and filtered through $1 \mu \mathrm{m}$ mesh. The daily mixed diet consisted of Isochrysis affinis galbana (CCAP 927/14) and Chaetoceros gracilis (UTEX LB2658) 1:1 in dry weight at a ration equivalent to $6 \%$ of the oyster dry weight. Once the oysters were reproductively mature, gametes from 30 individuals (1/3 males, 2/3 females), obtained by stripping, were mixed in a $5 \mathrm{l}$ jar at 50 spermatozoids per oocyte. The fertilized oocytes completed their embryonic development in $150 \mathrm{l}$ tanks filled with $1 \mu \mathrm{m}$ filtered and UV-treated seawater at $21^{\circ} \mathrm{C}$ for $24 \mathrm{~h}$. The D-larvae were then collected and reared in flow-through rearing systems at $25^{\circ} \mathrm{C}$ (Rico-Villa et al. 2008). At the end of the pelagic phase (12 d), competent larvae were collected on a $225 \mu \mathrm{m}$ sieve and allowed to settle on cultch. Postlarvae were maintained in downwelling systems where they were continuously supplied with enriched seawater. After $5 \mathrm{~d}$, the cultchless seed were collected on $400 \mu \mathrm{m}$ mesh and reared at $25^{\circ} \mathrm{C}$ in downwellers for 50 to $120 \mathrm{~d}$ depending on the experiment. In the larval and post-larval stages, the oysters were fed the same diet as the broodstock at a concentration of $1500 \mathrm{um}^{3} \mathrm{\mu l}^{-1}$ (Rico-Villa et al. 2009). Overall, 10 batches of standardized oyster seed (3 to 6 mo old, 0.2 to $1.2 \mathrm{~g}$ wet mass) were produced every $6 \mathrm{wk}$ for use in the experiments. They all remained free of any abnormal mortality, OsHV-1 DNA was not detected and the relative concentration of vibrios was low (Table 1). Thus, the 10 standardised batches were considered naive with regard to OsHV- $1 \mu$ Var. The likely minimum level of disease prevalence was $<30 \%$ (with $95 \%$ confidence level), considering that 10 oysters were analysed for OsHV-1 DNA detection by qPCR, and assuming that there is no loss of sensitivity due to pooling and that the population of oysters is infinite (Pfeiffer 2010).

Table 1. Characteristics of oyster seed used in Expts A-D. OsHV-1 DNA detection was performed on 2 pools of 5 oysters; only results from unexposed oysters are presented here. Bacterial analyses were conducted on 3 to 8 pooled oysters in duplicate or in triplicate. Biomass and Vibrio spp. data are means \pm SD. Arg: Argenton; AB: Aber Benoît; BB: Bay of Brest; nd: not detected; na: not available. Age was measured as months from fertilization to onset of experiment. Dates are presented as $\mathrm{dd} / \mathrm{mm} / \mathrm{yy}$

\begin{tabular}{|c|c|c|c|c|c|c|c|c|c|c|c|c|}
\hline \multirow{3}{*}{$\begin{array}{l}\text { Batch } \\
\text { no. }\end{array}$} & \multirow{3}{*}{$\begin{array}{l}\text { Condi- } \\
\text { tioning }\end{array}$} & \multirow{3}{*}{$\begin{array}{l}\text { Fertili- } \\
\text { zation }\end{array}$} & \multicolumn{2}{|c|}{ Experiments } & \multicolumn{4}{|c|}{ - Sites } & \multirow{3}{*}{$\begin{array}{l}\text { Age } \\
\text { (mo) }\end{array}$} & \multicolumn{2}{|c|}{ - Oysters } & \multirow{3}{*}{$\begin{array}{l}\text { Vibrio spp } \\
\quad(\%)\end{array}$} \\
\hline & & & \multirow[t]{2}{*}{ Onset } & \multirow[t]{2}{*}{ Type } & \multirow[t]{2}{*}{ Locations } & \multicolumn{3}{|c|}{ Temperature $\left({ }^{\circ} \mathrm{C}\right)$} & & \multirow{2}{*}{$\begin{array}{c}\text { Mass } \\
{\left.\text { (mg ind } .^{-1}\right)}^{2}\end{array}$} & \multirow{2}{*}{ OsHV-1 } & \\
\hline & & & & & & Arg & $\mathrm{AB}$ & BB & & & & \\
\hline 1 & $23 / 03 / 10$ & 03/05/10 & $15 / 07 / 10$ & A & Arg & 21.0 & & & 2.4 & $310 \pm 10$ & nd & $1.34 \pm 0.50$ \\
\hline 2 & $28 / 04 / 10$ & 09/06/10 & $25 / 08 / 10$ & A, C & Arg, $\mathrm{AB}$ & 21.0 & na & & 2.5 & $260 \pm 10$ & nd & $1.67 \pm 0.40$ \\
\hline 3 & 07/06/10 & $19 / 07 / 10$ & $08 / 10 / 10$ & A, C & Arg, $\mathrm{AB}, \mathrm{BB}$ & 21.0 & na & 16.3 & 2.7 & $337 \pm 12$ & nd & $0.25 \pm 0.10$ \\
\hline 4 & $17 / 07 / 10$ & $30 / 08 / 10$ & $22 / 11 / 10$ & $\mathrm{~A}, \mathrm{~B}, \mathrm{C}$ & Arg, $\mathrm{AB}, \mathrm{BB}$ & 21.0 & na & 11.6 & 2.8 & $263 \pm 12$ & nd & $0.23 \pm 0.10$ \\
\hline 5 & $30 / 08 / 10$ & $11 / 10 / 10$ & 03/01/11 & A, C & Arg, $A B, B B$ & 21.0 & 9.8 & 8.1 & 2.8 & $273 \pm 6$ & nd & $0.04 \pm 0.20$ \\
\hline 6 & $11 / 10 / 10$ & $22 / 11 / 10$ & 17/02/11 & A, C & Arg, AB, BB & 21.0 & 9.4 & 8.7 & 2.9 & $297 \pm 12$ & nd & $0.31 \pm 0.00$ \\
\hline 7 & $22 / 11 / 10$ & 05/01/11 & 05/04/11 & A, C & Arg, AB, BB & 21.0 & 11.5 & 12.9 & 3.0 & $333 \pm 15$ & nd & $0.11 \pm 0.10$ \\
\hline 8 & 10/01/11 & $22 / 02 / 11$ & $13 / 05 / 11$ & A & Arg & 21.0 & 14.6 & 16.4 & 2.6 & $343 \pm 6$ & nd & $0.00 \pm 0.00$ \\
\hline & & & $31 / 05 / 11$ & B & BB & & & 16.1 & 3.2 & $250 \pm 28$ & nd & $1.24 \pm 0.23$ \\
\hline 9 & $11 / 03 / 11$ & $12 / 04 / 11$ & 02/07/11 & A & Arg & 21.0 & 15.8 & 18.6 & 2.7 & $353 \pm 6$ & nd & $0.32 \pm 0.10$ \\
\hline & & & 04/07/11 & B & $\mathrm{BB}$ & & & 19.2 & 2.7 & $170^{\mathrm{a}}$ & nd & $0.08 \pm 0.09$ \\
\hline 10 & $23 / 04 / 11$ & 07/06/11 & 05/09/11 & $\mathrm{A}$ & Arg & 21.0 & 15.6 & 18.8 & 3.0 & $327 \pm 6$ & nd & $1.08 \pm 0.70$ \\
\hline & & & $10 / 10 / 11$ & D (water renewal) & $\mathrm{Arg}, \mathrm{BB}$ & 21.0 & & 16.5 & 4.1 & $1076 \pm 171$ & nd & $0.00 \pm 0.00$ \\
\hline & & & $28 / 10 / 11$ & D (biomass) & Arg, BB & 21.0 & & 14.4 & 4.7 & $1230 \pm 409$ & nd & na \\
\hline
\end{tabular}




\section{Experimental design}

Expt A: effect of oyster seed origin on disease transmission and mortality risk

The objective of Expt A was to investigate whether disease transmission and the related mortality of oysters is influenced by their rearing history (i.e. exposure in the field versus rearing under hatchery/nursery conditions) (Fig. 1). To test this hypothesis, 83 batches of seed $(<1 \mathrm{yr})$ were collected between 2010 and 2014 (see Supplement 1 at www.int-res.com/ articles/suppl/q006p205_supp.pdf). A total of 51 batches were sampled from natural collection sites in France: Thau lagoon (3), Arcachon (10), MarennesOléron (14), Bourgneuf (7), Vilaine estuary (4), Quiberon (1) and the Bay of Brest (12). An additional 32 batches were obtained from nurseries-either public research facilities: Ifremer Argenton (24), Ifremer La Tremblade (2), or commercial hatcheries (6). Wild oyster seed were collected during the winter or early spring when seawater temperature was below $14^{\circ} \mathrm{C}_{i}$ no abnormal mortality occurred. Oyster seed from nurseries were collected all year, reflecting the fact that hatchery production of oysters is usually not synchronised with natural spawning. Oyster seed sampled in nurseries were 3 mo old, and their wet weight varied from 0.2 to $1.2 \mathrm{~g}$.

Animals were directly transferred to the Ifremer facilities in Argenton, where they were placed at $21^{\circ} \mathrm{C}$ in order to reactivate the virus in infected individuals. Survival was followed for $30 \mathrm{~d}$. Note that oysters originating from Argenton were held at $21^{\circ} \mathrm{C}$ all year, so they were previously acclimated for $10 \mathrm{~d}$ at $13^{\circ} \mathrm{C}$ before being re-exposed at $21^{\circ} \mathrm{C}$.

Additionally, 38 batches tested in 2013 and 2014 were placed in cohabitation with naïve oysters to further investigate whether transmission of the disease occurred (see Table S1 in the Supplement). These cohabitation trials were designed based on previous results which showed that it is possible to transmit disease and related mortality to healthy $C$. gigas seed in cohabitation experiments, by using oysters infected by a brief exposure to field conditions in which mortalities were occurring (Petton et al. 2013). The tested oyster seed $(n=150)$ were placed on one side of each tank and naïve oysters $(\mathrm{n}=100)$ were placed downstream, on the opposite side. These naïve oysters were hereafter referred to as 'challenged' animals.

Live and dead oysters were counted at the start of the experiment and after $30 \mathrm{~d}$. Dead animals were removed from the tank at each count. Duplicate pools of 5 oysters from each batch were sampled for OsHV-1 DNA detection (1) at the time of collection and (2) when mortality occurred, or after 10 to $15 \mathrm{~d}$ of acclimation at $21^{\circ} \mathrm{C}$.

Expt B: determination of the timing and duration of field exposure required to become diseased

The objective of this experiment was to determine the timing and duration of exposure to field conditions (where disease mortality of oysters naturally occurs) that is required for otherwise healthy individuals to become infected and exhibit mortality in a safe and controlled environment (Fig. 1). Sub-samples of oysters originating from batches 4 , 8 and 9 were transferred on 22 November 2010, 31 May 2011 and 4 July 2011 respectively (Table 1) to a farming area located in the Bay of Brest at Pointe du Château $\left(48^{\circ} 20^{\prime} 6^{\prime \prime} \mathrm{N}, 4^{\circ} 19^{\prime} 6^{\prime \prime} \mathrm{W}\right)$. Experimental oysters were placed in duplicate mesh bags (ca. 150 ind. bag $^{-1}$ ) attached to iron tables. Seawater temperatures were $11.6,16.1$ and $19.2^{\circ} \mathrm{C}$, respectively (Table 1 ). The experimental oysters were exposed to field conditions for 42, 73, 102, $135,149$ or $162 \mathrm{~d}$ (batch 4$) ; 6,9,13,17$ or $20 \mathrm{~d}$ (batch 8 ); or $4,6,8,10$ or $12 \mathrm{~d}$ (batch 9). The field-exposed oysters did not show significant mortality during the exposure periods. Sub-samples of the exposed oyster batches were left in the field to examine whether they suffered mortalities later.

Following field exposure, oysters were transferred back to the Ifremer facilities in Argenton where they were placed in rectangular 231 plastic tanks at $21^{\circ} \mathrm{C}$. Each tank contained all oysters originating from 1 mesh bag ( $\mathrm{n}=2$ tanks for each condition with 150 ind. $\operatorname{tank}^{-1}$ ). Each tank was supplied with $1 \mu \mathrm{m}$ filtered seawater exposed to UV irradiation flowing at $100 \mathrm{ml} \mathrm{min}^{-1}$ (Petton et al. 2013). Live and dead animals were counted every 1 to $2 \mathrm{~d}$, and dead animals were removed from the tanks. For each batch, survival of unexposed oysters was followed in duplicate tanks (controls). OsHV-1 DNA detection was conducted on 5 pooled oysters sampled at the end of field exposure (the onset of the laboratory monitoring) for each replicate $(\mathrm{n}=2)$. Both fieldexposed and control oysters were analysed. Additionally, oysters that were left in the field for the entire duration of the experiment were sampled and analysed for OsHV-1 DNA detection by PCR (see 'Quantification of OsHV-1 DNA' below) when mortality occurred. 


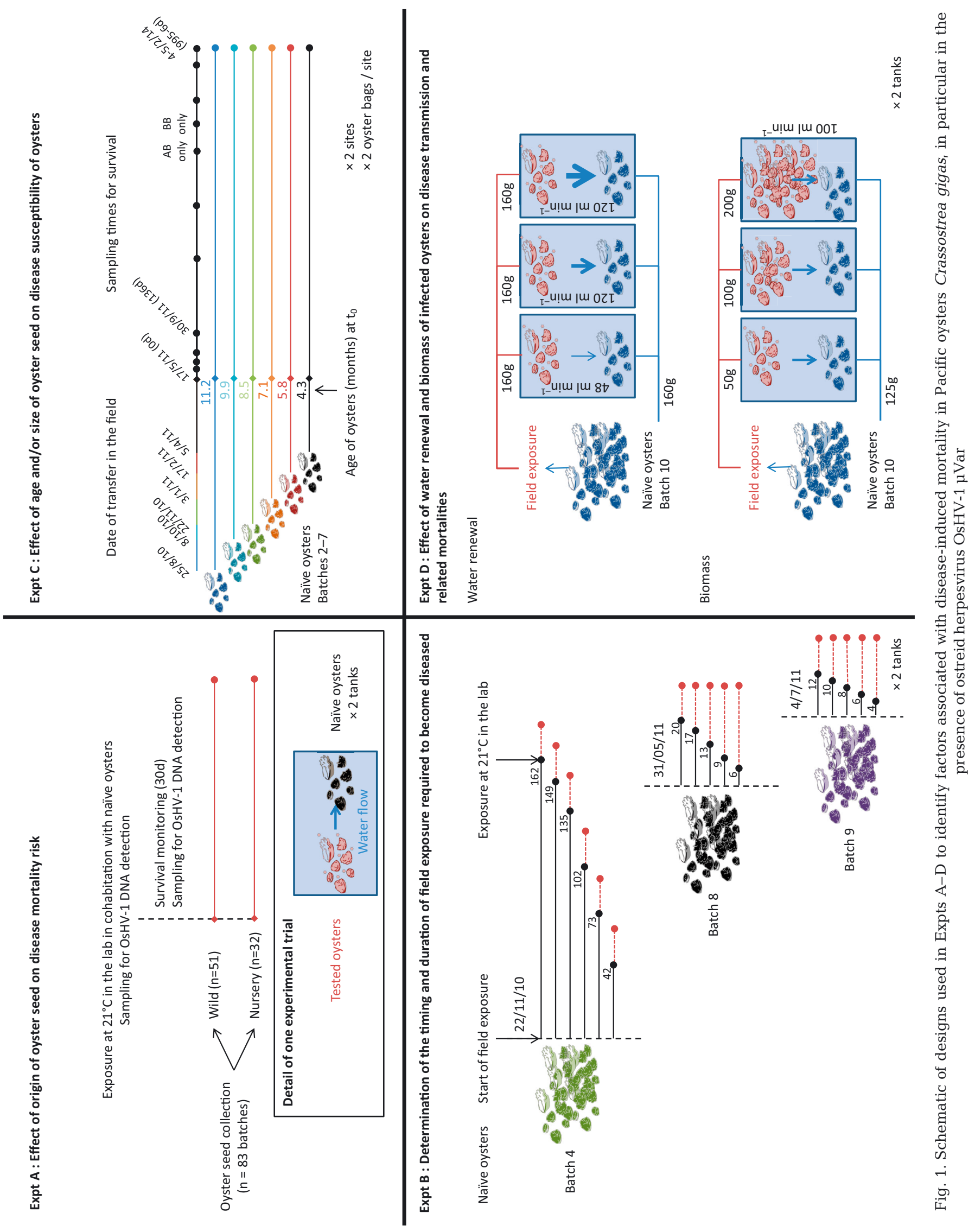


Expt C: effect of age and/or size of oyster seed on disease susceptibility

Sub-samples of 3 mo old oysters originating from batches 2 to 7 were transferred to the Bay of Brest at Pointe du Château, and to Aber Benoît on 25 August, 8 October and 22 November 2010, and on 3 January, 17 February and 5 April 2011 (Table 1). Oysters were placed in duplicate mesh bags (ca. 150 ind. bag $^{-1}$ ) attached to iron tables. These oysters did not show significant mortality between deployment and May 2011, except for animals deployed at the Bay of Brest on 25 August 2010 (batch 2), which exhibited 75\% mortality at the beginning of September. This batch was therefore not included in Expt $\mathrm{C}$ at the Bay of Brest. The age of the oysters was ca. 4.3, 5.8, 7.1, 8.5, 9.9 and 11.2 mo.

Survival of oysters was recorded on 2 and 17 May 2011 at the Bay of Brest and Aber Benoitt respectively, when the seawater temperature reached $16^{\circ} \mathrm{C}$ (a threshold temperature above which disease transmission is optimal and mortalities occur) and at the onset of the mass mortality (18 May and 15 June). Subsequently, survival of oysters was followed on 5 July, 4 August and 13-30 September 2011 in Aber Benoît and Bay of Brest, and every 4 to 6 mo thereafter until 4-5 February 2014. To evaluate the effect of size at age on survival, shell lengths of live and dead oysters contained in 1 of the 2 bags transferred to Aber Benoit were measured on 15 June 2011, when mass mortality occurred.

In this experiment, age was confounded with duration of field exposure before the onset of mortality. Therefore, to separate these 2 effects, a complementary experiment was performed (see Supplement 2 at www.int-res.com/articles/suppl/q006p205_supp.pdf). Briefly, oysters from batches 5 and 7 (aged 7.1 and 4.3 mo respectively at the onset of mortality) were transferred twice to the Bay of Brest: oysters from batch 5 were transferred on 3 January (long exposure $=89 \mathrm{~d}$ ) and later on 5 April (short exposure = $41 \mathrm{~d})$, whereas those from batch 7 were transferred on 5 April (long exposure $=41 \mathrm{~d}$ ) and later on 3 May (short exposure $=13 \mathrm{~d}$ ). Survival of these animals was followed for 1 yr until 3 May 2012.

Expt D: effect of water renewal and biomass of infected oysters on disease transmission and mortality

The objective of Expt D was to investigate the effect of water renewal and biomass of infected animals on disease transmission and related mortalities of oysters under experimental tank conditions. Subsamples of oysters originating from batch 10 were exposed to field conditions in the Bay of Brest at Pointe du Château on 12 September and 1 October 2011 for the water renewal and biomass experiment respectively, when seawater temperature was 18.4 and $16.1^{\circ} \mathrm{C}$, respectively.

On 10 October, these previously field-exposed oysters were transferred back to the Ifremer facilities in Argenton where they were placed randomly in duplicate rectangular 231 plastic tanks in contact with naïve oysters at 3 different water renewal rates $(48$, 120 and $280 \mathrm{ml} \mathrm{min}^{-1}$ ). A total of 100 exposed oysters (total biomass $=160 \mathrm{~g}$ ) were placed on one side of each tank, whereas another 135 naïve oysters (160 g) were placed downstream, on the opposite side.

Similarly, on 28 October, 3 different biomasses of exposed oysters $(50,100$ and $200 \mathrm{~g})$ were placed in duplicate 231 tanks in contact with naïve oysters $(75$ animals, total biomass $=125 \mathrm{~g}$, hereafter referred to as 'laboratory challenged' animals). Water renewal was maintained at a constant rate of $100 \mathrm{ml} \mathrm{min}^{-1}$.

Live and dead oysters were counted at the start of the experiments and after 1,2, 4, 7, 11, 14 and $19 \mathrm{~d}$ (for the water renewal experiment) or after 7,11 and $19 \mathrm{~d}$ (for the biomass experiment). Dead animals were removed from the tank at each count. Exposed oysters were sampled for OsHV-1 DNA detection at the onset of the experiment and after 2 and $4 \mathrm{~d}$.

\section{Monitoring of seawater temperature in the field}

Seawater temperatures were provided by the Resco/ Velyger Ifremer networks (http://wwz.ifremer.fr/ velyger). Temperatures have been recorded every 30 min since March 2009 using multi-parameters probes (NKE Instrumentation) deployed at our experimental sites in the Bay of Brest at Pointe du Château $\left(48^{\circ} 20^{\prime} 06.19^{\prime \prime} \mathrm{N}, 4^{\circ} 19^{\prime} 06.37^{\prime \prime} \mathrm{W}\right)$ and at Aber Benoît (4834' 29.976" N, 4³6' 18.378" W).

\section{OsHV-1 and vibrios analyses}

Oysters sampled for OsHV-1 DNA detection were stored at $-20^{\circ} \mathrm{C}$ until analysis. DNA extraction and OsHV-1 detection by PCR were performed by IDHESA Bretagne Océane (Quimper).

\section{Quantification of OsHV-1 DNA}

Total DNA was extracted from an aliquot of tissue sample using a QIAgen QIAamp tissue mini kit, according to the manufacturer's protocol. The extracted 
DNA was stored at $-20^{\circ} \mathrm{C}$ prior to analysis. The detection and quantification of OsHV-1 DNA was carried out using a previously published real-time PCR protocol (Pepin et al. 2008). Briefly, this protocol uses SYBR® Green chemistry with specific DPFor/Rev primers targeting the region of the OsHV-1 genome predicted to encode a DNA polymerase catalytic subunit (Webb et al. 2007). The specificity and sensitivity of the detection test using these primers is similar to those reported by Pepin et al. (2008) (T. Renault pers. comm.). The method used in our study was the recommended method for reasons of availability, utility, and diagnostic specificity and sensitivity for OsHV-1 detection (OIE 2012, www.oie.int/fileadmin/Home/eng/ Health_standards/aahm/2010/2.4.09_INF_OSTREID_ HERPES.pdf). Results were expressed as viral DNA copy numbers $\mathrm{mg}^{-1}$ wet tissue.

\section{Targeted detection of OsHV-1 $\mu$ Var}

The standard real-time PCR using SYBR Green cannot differentiate OsHV-1 reference from OsHV-1 $\mu$ Var. Therefore, specific primers were used to distinguish the 'reference' and ' $\mu$ Var' genotypes by comparison with positive controls (see Appendix B in EFSA 2010, Council regulation 175/2010). These complementary OsHV-1 $\mu$ Var specific PCR analyses were performed every 30 samples in which OsHV-1 DNA had first been detected. The OsHV-1 $\mu$ Var-specific PCR analyses detected the OsHV-1 $\mu$ Var genotype only, which agrees well with the fact that in 2009 the OsHV-1 $\mu$ Var had fully replaced the reference OsHV-1 genotype in seed presenting mortality at all French oyster production sites (Segarra et al. 2010, Martenot et al. 2011, Renault et al. 2012). Therefore, in the present study we refer to 'OsHV-1' as 'OsHV-1 $\mu$ Var'.

\section{Quantification of vibrios}

Whole tissue samples of a pool of 3 to 8 oysters per batch, diluted in sterilized seawater (1:100), were spread on marine broth medium and thiosulphate citrate bile salts-sucrose (TCBS) in Petri dishes to quantify cultivable bacteria, and more specifically, vibrios (Petton et al. 2013). The bacteriological media used in this study were obtained from Difco Laboratories. The plates were incubated at $22.5^{\circ} \mathrm{C}$ for $6 \mathrm{~d}$ in marine broth, and for $2 \mathrm{~d}$ in TCBS before counting the number of colony forming units (CFU, Table 1). Data are expressed as \% Vibrio spp. $(100 \times \mathrm{CFU}$ of vibrios / CFU of total cultivable bacteria).

\section{Statistical analyses}

Statistical analyses were conducted using LIFETEST, LOGISTIC and PHREG procedures of the SAS software package (SAS v.9.4, SAS institute). A significance threshold of $\alpha=0.05$ was adopted for all statistical tests.

\section{Lifetest}

Nonparametric estimates of the survivor function were computed by the Kaplan-Meier method (Kaplan \& Meier 1958). Survival time was measured as days from the onset of the experiment, when oysters were transferred back to the Ifremer facilities in Argenton at $21^{\circ} \mathrm{C}$. The data were read as the number of dead animals within each experimental unit at each time interval. Survival curves of oysters were compared among treatments (Expt B: duration of field exposure at each season; Expt C: age and/or size, duration of field exposure; Expt D: water renewal and biomass of infected oysters) and status (Expt D: previously fieldexposed or laboratory-challenged). The resulting survival estimates were compared by using the log-rank test of homogeneity of strata.

\section{Logistic regression}

A logistic regression model was used to investigate the effect of exposure to field conditions on the occurrence of mortality, and the effect of detecting OsHV-1 DNA in oyster tissues before and during exposure at $21^{\circ} \mathrm{C}$ in the laboratory (Expt A). The model predicts the probability of a 1 for mortality and a 0 for absence of mortality. Mortality was considered significant when $>5 \%$. The variable origin was coded 0 if oysters were from a nursery, 1 for wild oysters. OsHV-1 DNA detection in oysters was coded 0 if not detected, 1 for detected.

\section{Cox regression}

The survival time curves of oysters were compared using the Cox regression model (Cox 1972), after adjustment for the effect of some static covariates such as age for each site (Expt C) or water renewal and biomass of infected oysters and status (previously field-exposed or laboratory-challenged, Expt D). The proportionality of hazards (PH) was checked with martingale residuals (Lin et al. 1993, Lee \& 
Wang 2013). Because the PH assumption was violated, time-dependent covariates representing the interaction of the original covariates and time were added to the model. Time $(t)$ was defined as dichotomous: $t \leq 136 \mathrm{~d}$ or $t>136 \mathrm{~d}$ (Expt C) and $t \leq 7 \mathrm{~d}$ or $t>$ $7 \mathrm{~d}$ (Expt D). These time intervals contained a sufficient number of deaths to estimate regression coefficients reliably (Anderson \& Senthilselvan 1982, Hess 1995). Custom hazard ratios were produced by means of polynomial (linear) contrasts.

\section{RESULTS}

\section{Effect of origin of oyster seed on disease mortality risk (Expt A)}

The survival of oysters collected between 2010 and 2014 from 7 seed collection sites (51 batches) and 5 nurseries (32 batches), when seawater temperature was $<14^{\circ} \mathrm{C}$, was followed for $30 \mathrm{~d}$ at $21^{\circ} \mathrm{C}$ under laboratory conditions in duplicate tanks (i.e. trials). OsHV-1 DNA detection analyses were conducted twice: at the time of collection and when mortality occurred, or after 10 to $15 \mathrm{~d}$ of acclimation at $21^{\circ} \mathrm{C}$.

Most batches collected from nurseries did not exhibit mortality at $21^{\circ} \mathrm{C}$ under laboratory conditions, and OsHV-1 DNA was not detected during survival monitoring. Furthermore, challenged oysters placed in cohabitation for $30 \mathrm{~d}$ with oysters collected from hatcheries showed no mortality; thus there was no disease transmission. Only 1 batch (no. 10) out of 32 tested (2/63 trials; Table 2) sampled from a nursery showed significant mortality and was positive for the detection of OsHV-1 DNA (see Supplement 1).

By contrast, 31/51 batches collected from the wild (53/101 trials) showed significant mortalities at $21^{\circ} \mathrm{C}$ in at least 1 trial (Table 2). These mortalities corresponded to the detection of OsHV-1 DNA in oyster tissues before and/or during survival monitoring in 28/31 batches (50/53 trials; Table 2). In these cases, survival varied from 18 to $95 \%$ with a mean $( \pm \mathrm{SD})$ of $54 \pm 23 \%$. Also, chal- lenged oysters placed in cohabitation with diseased wild oysters showed significant mortalities in 28/31 trials, suggesting disease transmission occurred. It is noteworthy that mortalities were associated with the detection of OsHV-1 DNA in only 3/53 trials. However, only one of these trials showed high mortality in both collected and challenged oysters (survival was $60.2 \%$ in collected oysters and $75.2 \%$ in challenged animals in 1 of 2 trials of batch 68 ; see Supplement 1 ). The other 2 trials exhibited 91.3 and $94.5 \%$ survival, and challenged oysters showed no mortalities (see batches 69 and 66, respectively in Supplement 1).

Lack of significant mortality in wild oysters at $21^{\circ} \mathrm{C}$ was associated with the absence of OsHV-1 DNA in their tissues in 28/48 trials, and the challenged oysters placed in cohabitation with these wild oysters showed no mortality (Table 2). Conversely, OsHV-1 DNA had been detected in wild oysters although no mortality occurred in 20/48 trials, and the challenged oysters showed no mortality, suggesting there was no disease transmission.

Overall, the odds of mortality at $21^{\circ} \mathrm{C}$ under laboratory conditions were 27 times higher in wild-collected oysters compared to those from nurseries (Table 3). Detection of OsHV-1 DNA in oysters at the time of collection was not predictive of mortality risk. When oysters were exposed at $21^{\circ} \mathrm{C}$, odds of mortality were 66 times higher when OsHV-1 DNA was detected than when it was not.

Table 2. Expt A. Mortality at $21^{\circ} \mathrm{C}$ and detection of ostreid herpesvirus 1 (OsHV-1) DNA in Pacific oyster Crassostrea gigas seed collected in the wild (51 batches) and in nurseries (32 batches). Data are number of trials corresponding to each combination of origin, mortality and OsHV-1 DNA detection. The numbers in parentheses indicate percentages based on the total amount of trials. Two trials were generally conducted for each batch of oysters $(n=83$ batches, 164 trials; see Supplement 1 at www.int-res.com/articles/suppl/q006p205_supp.pdf for further details). Mortality was also recorded in challenged oysters placed in cohabitation with a sub-sample of oysters collected in the wild (33 batches) and in nurseries (5 batches) to investigate whether transmission of the disease occurred. Mortality was considered significant when $>5 \%$. Values in bold indicate the most common combinations $(>10 \%)$; nd: not determined

\begin{tabular}{|c|c|c|c|c|c|c|c|}
\hline \multirow[t]{2}{*}{ Origin } & \multirow[t]{2}{*}{ Mortality } & \multicolumn{2}{|c|}{ OsHV-1 DNA detection } & \multirow{2}{*}{$\begin{array}{c}\text { No. of trials } \\
(\%)\end{array}$} & \multicolumn{3}{|c|}{ Mortality in challenged oysters } \\
\hline & & Initial & At $21^{\circ} \mathrm{C}$ & & No & Yes & nd \\
\hline \multirow[t]{2}{*}{ Nursery } & No & No & No & $61(37.2)$ & \multirow[t]{2}{*}{$10(6.1)$} & \multirow[t]{2}{*}{$0(0.0)$} & $51(31.1)$ \\
\hline & Yes & Yes & Yes & $2(1.2)$ & & & $2(1.2)$ \\
\hline \multirow[t]{7}{*}{ Wild } & No & No & No & $28(17.1)$ & $24(14.6)$ & $0(0.0)$ & $4(2.4)$ \\
\hline & No & No & Yes & $15(9.1)$ & $6(3.7)$ & $0(0.0)$ & $9(5.5)$ \\
\hline & No & Yes & No & $1(0.6)$ & $1(0.6)$ & $0(0.0)$ & $0(0.0)$ \\
\hline & No & Yes & Yes & $4(2.4)$ & $1(0.6)$ & $0(0.0)$ & $3(1.8)$ \\
\hline & Yes & No & No & $3(1.8)$ & $2(1.2)$ & $1(0.6)$ & $0(0.0)$ \\
\hline & Yes & No & Yes & $39(23.8)$ & $3(1.8)$ & $19(11.6)$ & $17(10.4)$ \\
\hline & Yes & Yes & Yes & $11(6.7)$ & $0(0.0)$ & $9(5.5)$ & $2(1.2)$ \\
\hline Total & - & - & - & $164(100.0)$ & $47(28.7)$ & $29(17.7)$ & $88(53.7)$ \\
\hline
\end{tabular}


Table 3. Expt A. Logistic regressions examining the effects on survival of the origin of Pacific oyster Crassostrea gigas seed (wild or nursery) and detection of OsHV-1 DNA before and during thermal elevation in the laboratory at $21^{\circ} \mathrm{C}$. For each factor, the following elements are given: its parameter estimate, standard error, chi-square and the resulting p-value for the Type II test from the complete model. The corresponding instantaneous odds ratio and the confidence interval are also provided. Significant $p$-values $(p<0.05)$ are in bold

\begin{tabular}{|lrrrrrrr|}
\hline Source of variation & df & Estimate & SE & $\chi^{2}$ & $\mathrm{p}$ & Odds ratio & $95 \%$ CI \\
\hline $\begin{array}{l}\text { Origin of oysters } \\
\text { Intercept }\end{array}$ & 1 & -3.2 & 0.7 & 24.3 & $\mathbf{< 0 . 0 0 1}$ & & \\
$\quad$ Origin & 1 & 3.3 & 0.7 & 23.6 & $\mathbf{< 0 . 0 0 1}$ & 27.1 & $7.2-102.9$ \\
$\begin{array}{l}\text { Detection of OsHV-1 DNA } \\
\text { Intercept }\end{array}$ & 1 & -3.3 & 0.5 & 35.3 & $\mathbf{< 0 . 0 0 1}$ & & \\
$\quad$ OsHV-1 initial & 1 & 0.2 & 0.6 & 0.1 & 0.809 & 1.2 & $0.3-4.0$ \\
OsHV-1 at $21^{\circ} \mathrm{C}$ & 1 & 4.2 & 0.6 & 45.2 & $\mathbf{< 0 . 0 0 1}$ & 66.1 & $19.5-224.1$ \\
\hline
\end{tabular}

\section{Determination of the timing and duration of field exposure required to become diseased (Expt B)}

The oysters deployed in the Bay of Brest at Pointe du Chateau on 22 November 2010 for 42 to 149 d (until 20 April 2011 when average seawater tempera- ture was $14.8^{\circ} \mathrm{C}$ ) exhibited $100 \%$ survival when exposed to a temperature elevation at $21^{\circ} \mathrm{C}$ in the laboratory (Fig. 2A). OsHV-1 DNA was not detected in these animals ( 0 out of 10 pools of 5 oysters; Table 4). Survival of oysters left in the field for $162 \mathrm{~d}$ (until 3 May 2011, average seawater temperature was $15.3^{\circ} \mathrm{C}$ ) and then transferred to the laboratory at $21^{\circ} \mathrm{C}$ was only $28.4 \%$ in one replicate but $100 \%$ in the other (mean $=64.2 \% ;$ Fig. 2A). The level of OsHV-1 DNA in oysters sampled in the mesh bag where mortality occurred was $4.1 \times 10^{6}$ copies $\mathrm{mg}^{-1}$ wet tissue (Table 4 ), which is 2 orders of magnitude higher than the threshold value of $10^{4}$ DNA copies $\mathrm{mg}^{-1}$ wet tissue, at which OsHV-1 is considered to be involved in mortality (Oden et al. 2011, Schikorski et al. 2011a). It is noteworthy that oysters left in the field exhibited
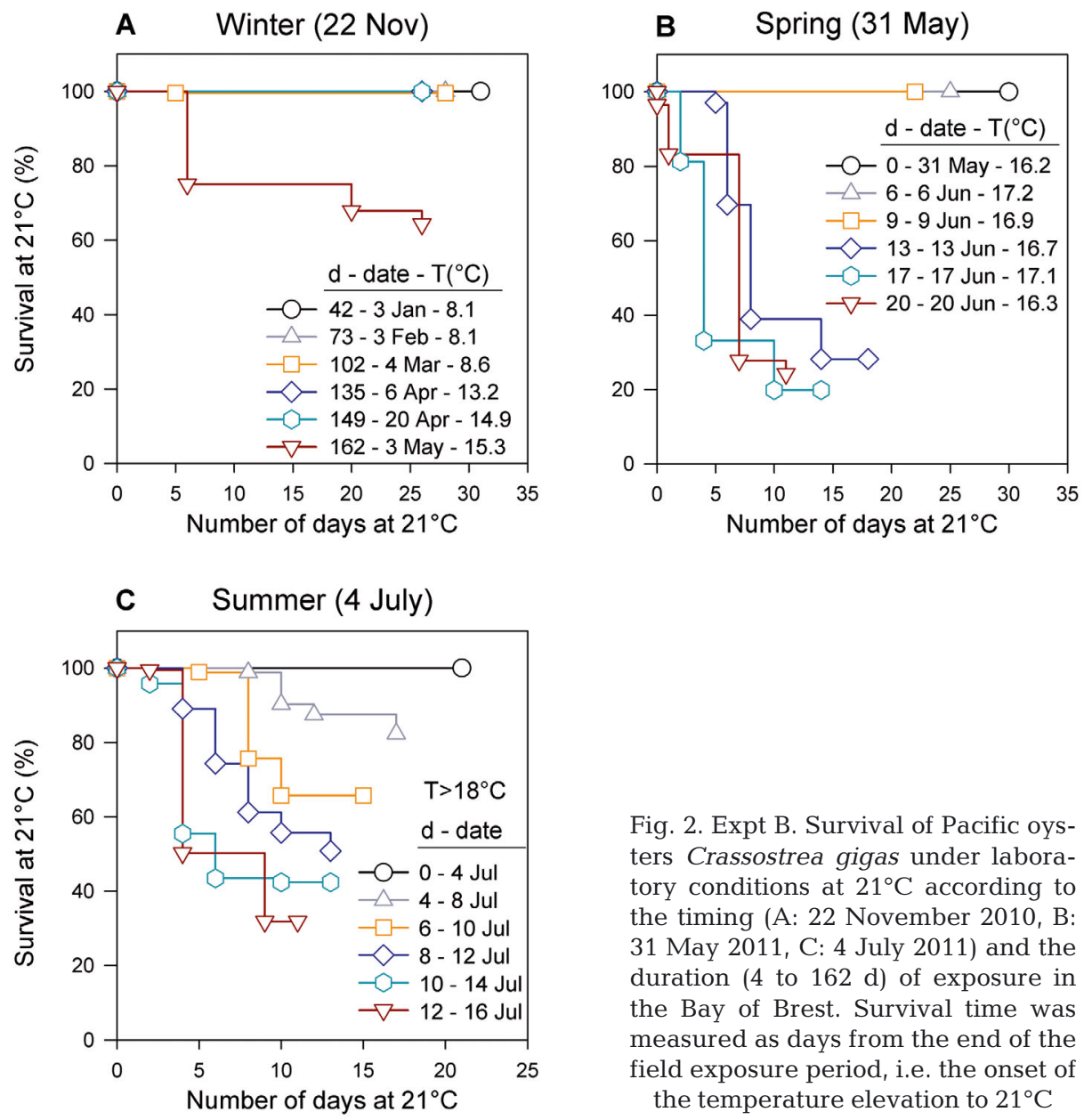

Fig. 2. Expt B. Survival of Pacific oysters Crassostrea gigas under laboratory conditions at $21^{\circ} \mathrm{C}$ according to the timing (A: 22 November 2010, B: 31 May 2011, C: 4 July 2011) and the duration (4 to 162 d) of exposure in the Bay of Brest. Survival time was measured as days from the end of the field exposure period, i.e. the onset of the temperature elevation to $21^{\circ} \mathrm{C}$ 
Table 4. Expt B. Detection of OsHV-1 DNA in Pacific oysters Crassostrea gigas exposed to field conditions in the Bay of Brest on 22 November 2010, 31 May 2011 and 4 July 2011 for 4 to 163 d and further exposed to a temperature elevation to $21^{\circ} \mathrm{C}$ in the laboratory. Day 0 corresponds to oysters not exposed to field conditions (i.e. control). The oysters used for OsHV-1 DNA detection were sampled at the end of the field exposure period, i.e. the onset of the temperature elevation to $21^{\circ} \mathrm{C}_{i}$ nd: not detected

\begin{tabular}{|lcccc|}
\hline $\begin{array}{l}\text { Date of field } \\
\text { exposure }\end{array}$ & $\begin{array}{c}\text { Duration of } \\
\text { exposure (d) }\end{array}$ & $\begin{array}{c}\text { OsHV-1 DNA } \\
\text { (log copies } \text { mg }^{-1} \text { ) }\end{array}$ & $\begin{array}{c}\text { No. of posi- } \\
\text { tive samples }\end{array}$ & $\begin{array}{c}\text { Mor- } \\
\text { tality }\end{array}$ \\
\hline 22 November & 0 & nd & $0 / 2$ & No \\
2010 & 42 & nd & $0 / 2$ & No \\
& 73 & nd & $0 / 2$ & No \\
& 102 & nd & $0 / 2$ & No \\
& 135 & nd & $0 / 2$ & No \\
& 149 & nd & $0 / 2$ & No \\
31 May 2011 & 162 & nd & $1 / 2$ & Yes \\
& 0 & nd & $0 / 2$ & No \\
& 6 & nd & $0 / 2$ & No \\
& 13 & $6.1 \pm 2.1$ & $2 / 2$ & Yos \\
& 17 & $6.9 \pm 0.6$ & $2 / 2$ & Yes \\
4 July 2011 & 20 & $8.5 \pm 0.5$ & $2 / 2$ & Yes \\
& 0 & nd & $0 / 4$ & No \\
& 4 & nd & $0 / 2$ & Yes \\
& 6 & nd & $0 / 2$ & Yes \\
& 8 & nd & $0 / 2$ & Yes \\
& 10 & nd & $0 / 2$ & Yes \\
& 12 & $4.9 \pm 0.5$ & $2 / 2$ & Yes \\
\hline
\end{tabular}

$70 \%$ mortality on 16 May, concomitant with high levels of OsHV-1 DNA (data not shown).

The oysters deployed at the Bay of Brest on 31 May for only 6 to $9 \mathrm{~d}$ while seawater temperature was $>16^{\circ} \mathrm{C}$ exhibited $100 \%$ survival when exposed to a temperature increase to $21^{\circ} \mathrm{C}$ in the laboratory (Fig. 2B), and OsHV-1 DNA was not detected in their tissues (Table 4). By contrast, mean survival of oysters left in the field for 13 to $20 \mathrm{~d}$ was only $24.0 \%$ in the laboratory at $21^{\circ} \mathrm{C}$, and OsHV-1 DNA was detected in all oyster samples (Fig. 2B, Table 4). Overall, final survival of oysters decreased with duration of field exposure. Oysters left in the field exhibited high levels of OsHV-1 DNA in their tissues

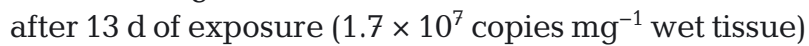
and survival decreased markedly thereafter $(92 \pm 1 \%$ after $21 \mathrm{~d}$ and $38 \pm 4 \%$ after $31 \mathrm{~d}$; data not shown).

Finally, the oysters deployed to the field on 4 July 2011 while seawater temperature was $>18^{\circ} \mathrm{C}$ exhibited significant mortalities after only $4 \mathrm{~d}$ of exposure (Fig. 2C). Survival of oysters decreased from 100 to $32 \%$ with duration of field exposure (Fig. 2C). However, OsHV-1 DNA was detected only in oysters exposed to field condition for $12 \mathrm{~d}$ (Table 4). Oysters left in the field exhibited high levels of OsHV-1 DNA in their tissues after $14 \mathrm{~d}$ of exposure $(2.5 \times$
$10^{6}$ copies $\mathrm{mg}^{-1}$ wet tissue), and survival decreased markedly thereafter $(54 \pm 2 \%$ after $21 \mathrm{~d}$ ) (data not shown).

\section{Effect of age and size of oyster seed on disease susceptibility (Expt C)}

Survival of oysters of 4.3 to 11.2 mo of age was followed from May 2011 until February 2014 in Aber Benoît and in the Bay of Brest. In the Bay of Brest, daily average seawater temperature fluctuated seasonally between 7.5 and $21.0^{\circ} \mathrm{C}$, whereas in Aber Benoît it varied from 6.5 to $17.0^{\circ} \mathrm{C}$ (Fig. 3).

Final survival of oysters maintained at Aber Benoît was $44.1 \%$ compared to $25.7 \%$ in the Bay of Brest (log-rank, p < 0.001). Also, the onset of oyster mortality occurred between 2 and 17 May at the Bay of Brest, where daily average maximum seawater temperature was $17.2^{\circ} \mathrm{C}$, whereas in Aber Benoît, mortality began later (between 17 May and 15 June), while daily average maximum seawater temperature was only $15.0^{\circ} \mathrm{C}$ (Fig. 3). The onset of mortality coincided with the detection of OsHV-1 DNA in oyster tissues both in the Bay of Brest (see results of Expt A) and in Aber Benoît, where oysters exhibited $2.1 \times 10^{7} \pm 2.3 \times 10^{7}$ copies OsHV-1 DNA mg $^{-1}$ tissue ( $\mathrm{n}=2$ samples).

Survival of oysters varied as a function of age and time both at Aber Benoît (Cox non-proportional hazard model, age $\times$ time [ $>136 \mathrm{~d}]$, Wald $\chi^{2}=114.0, \mathrm{p}<$ 0.001 ) and Bay of Brest (age $\times$ time $[>136 \mathrm{~d}]$, Wald $\chi^{2}$ $=54.5, \mathrm{p}<0.001)$. In the first $136 \mathrm{~d}$ after disease outbreak, parameter estimates for linear effects of age on survival were significant at both sites (Table 5). Based on these estimates, we calculated that an increase of $5.7 \mathrm{mo}$ of age in oysters reduced the odds of mortality by $44 \%\left(7.7 \% \mathrm{mo}^{-1}\right)$ in Aber Benoît. Similarly, in the Bay of Brest, odds of mortality during the first $136 \mathrm{~d}$ after disease outbreak decreased by $35 \%$ with an age increase of $4.4 \mathrm{mo}\left(7.9 \% \mathrm{mo}^{-1}\right)$.

During the next time period (136 to $995 \mathrm{~d}$ ), parameter estimates for a linear effect of age were either not significant (Aber Benoît) or only marginally significant (Bay of Brest; Table 5), highlighting the fact that the effect of age becomes progressively less important with time. In Bay of Brest, the probability of mortality increased with the age of oysters, reflecting the fact that it was higher in 9.9 mo old oysters compared to that of the other age groups (Fig. 3, Table 5). 

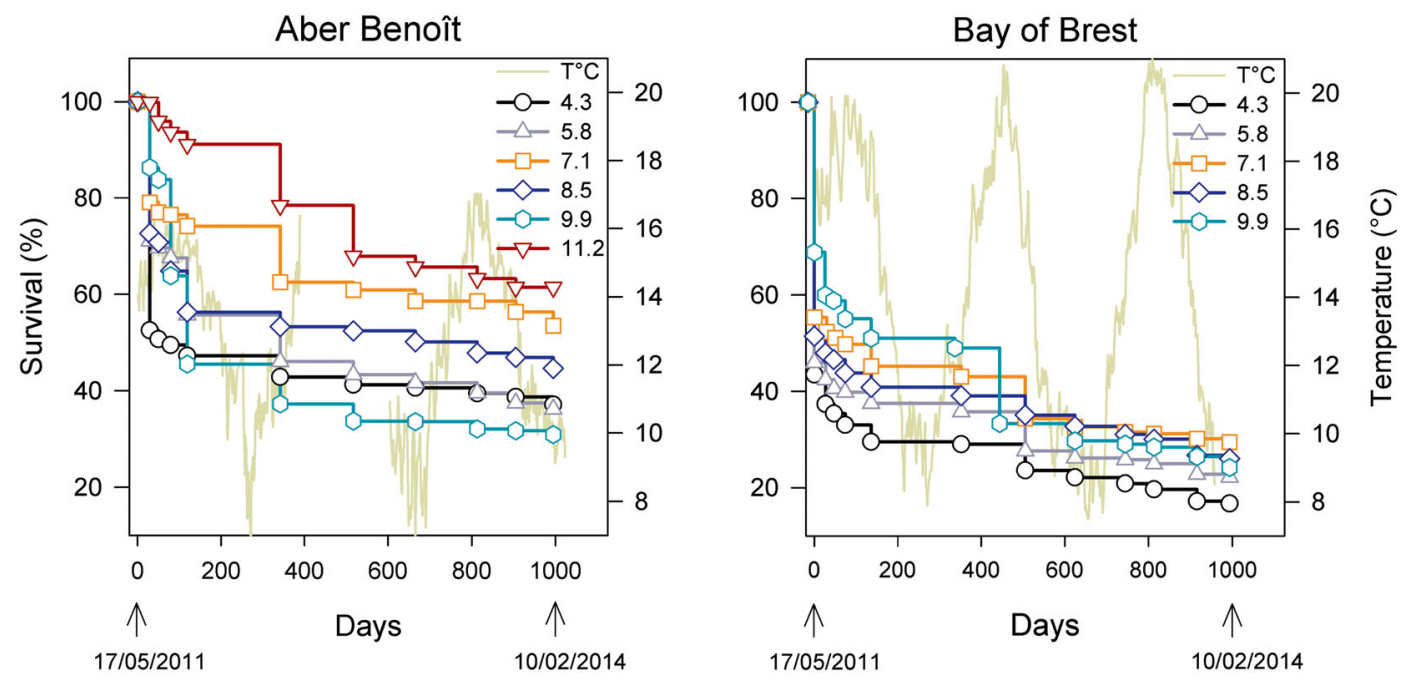

Fig. 3. Expt C. Survival of Pacific oysters Crassostrea gigas exposed to field conditions in Aber Benoît or the Bay of Brest according to their age (in mo) at the onset of mortality, in relation to seawater temperature. Survival time was measured as days from the onset of mass mortalities in the Bay of Brest

Final survival of oysters increased from 30.9 to $61.4 \%$ in Aber Benoît and from 16.7 to $29.4 \%$ in the Bay of Brest in a manner consistent with oyster age (Fig. 3). The only exception was 9.9 mo old oysters, which exhibited relatively high mortalities at both sites.

In our study, age and size of oysters were positively correlated (whole body mass $=0.573 \times$ age -1.012 ; $\left.\mathrm{r}^{2}=0.953\right)$. Therefore, the effect of oysters' whole body mass on survival was similar to that of age (data not shown) and these 2 factors are confounded. However, there was no difference in size (shell length) between dead and live oysters measured after the onset of mortality in Aber Benoît on 15 June 2011, suggesting that disease mortality affected small and large animals similarly (Fig. 4; ANCOVA on shell length with age as a covariate and status as a fixed factor, status $p=0.697$, age $\times$ status $p=0.833$ ).

In our study, age and duration of field exposure were confounded factors. In a complementary experiment (see Supplement 2), we observed that survival clearly increased with age but slightly decreased with duration of field exposure. Therefore, it seemed that the effect of age was much more important than that of duration of field exposure.

\section{Effect of water renewal and biomass of infected oysters on disease transmission and related mortalities (Expt D)}

Survival of oysters varied as a function of status, water renewal and time (Fig. 5A,B; Cox non-proportional hazard model, status $\times$ water renewal $\times$ time [>7d], Wald $\left.\chi^{2}=8.0, p=0.018\right)$. In the first $7 \mathrm{~d}$ of the experiment, parameter estimates for linear effects of water renewal on survival of exposed and challenged animals were significant (Table 6). Based on these estimates, we calculated that an increase of $167 \mathrm{ml}$ $\min ^{-1}$ would reduce the odds of mortality by 40 and $47 \%$ for exposed and challenged oysters respectively.

During the next period ( 7 to $19 \mathrm{~d}$ ), parameter estimates for linear effects of water renewal on survival of exposed and challenged animals were much lower than those observed during the previous time period (Table 6). Indeed, an increase of $167 \mathrm{ml} \mathrm{min}^{-1}$ would reduce the odds of mortality by $79 \%$ in exposed oysters, and $90 \%$ in challenged ones. Final survi-

Table 5. Expt C. Odds of disease mortality as a function of age of Pacific oysters Crassostrea gigas (varying from 4.3 to 11.2 mo old) in Aber Benoît and in the Bay of Brest for each time interval ( 0 to $136 \mathrm{~d}$ and 136 to $995 \mathrm{~d}$ ). Custom hazard ratios were produced by means of polynomial (linear) exponentiated contrasts. The table also contains the standard error (SE) of the hazard ratio estimate and the confidence interval (CI) on the hazard ratio, the Wald $\chi^{2}$ statistic and the resulting $\mathrm{p}$-value

\begin{tabular}{|lccccc|}
\hline Variable & $\begin{array}{l}\text { Odds } \\
\text { ratio }\end{array}$ & SE & $95 \%$ CI & Wald $\chi^{2}$ & $p$ \\
\hline Age (linear) & & & & & \\
Aber Benoît & & & & & \\
$0-136$ d & 0.558 & 0.044 & $0.479-0.651$ & 55.0 & $<0.001$ \\
$136-995$ d & 1.072 & 0.207 & $0.735-1.565$ & 0.1 & 0.718 \\
Bay of Brest & & & & & \\
$0-136$ d & 0.652 & 0.035 & $0.587-0.724$ & 64.2 & $<0.001$ \\
$136-995$ d & 1.362 & 0.188 & $1.039-1.785$ & 5.0 & 0.025 \\
\hline
\end{tabular}




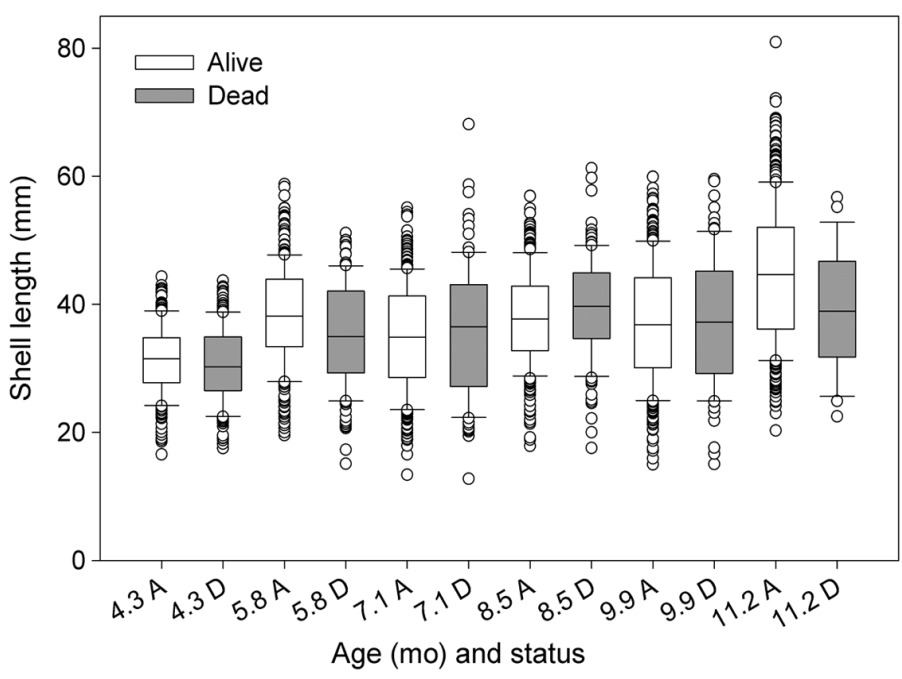

Fig. 4. Expt C. Box-plot of shell length of Pacific oysters Crassostrea gigas as a function of their age and status (alive, A or dead, D) in Aber Benoît on 15 June 2011, after the onset of mortality

val increased with water renewal rate from 12.3 to $53.1 \%$ in exposed oysters and from 6.9 to $78.4 \%$ in challenged animals (Fig. 5A,B).

The level of OsHV-1 DNA in exposed oysters at the onset of the experiment was $4.1 \times 10^{6} \pm 3.6 \times 10^{6}$ copies $\mathrm{mg}^{-1}$ wet tissue $(\mathrm{n}=2$ samples, data not shown), which is 2 orders of magnitude higher than the threshold value of $10^{4}$ DNA copies $\mathrm{mg}^{-1}$ wet tissue at which OsHV-1 is considered to be involved in mortality (Oden et al. 2011, Schikorski et al. 2011a). After 2 and $4 \mathrm{~d}$, the level of OsHV-1 DNA in exposed oysters increased, reaching $3.9 \times 10^{7} \pm 3.9 \times 10^{7}$ copies $\mathrm{mg}^{-1}$ wet tissue ( $\mathrm{n}=3$ samples) and $2.4 \times 10^{7} \pm 4.5 \times 10^{7}$ copies $\mathrm{mg}^{-1}$ wet tissue $(\mathrm{n}=4$ samples) respectively.

Survival of oysters varied as a function of status, biomass of infected oysters and time (Fig. 5C,D; Cox non-proportional hazard model, status $\times$ biomass $\times$ time $[>7 \mathrm{~d}]$, Wald $\left.\chi^{2}=17.5, \mathrm{p}<0.001\right)$. In the first $7 \mathrm{~d}$ of the experiment, the parameter estimates for linear effects of biomass of infected oysters on survival of exposed animals was significant (Table 6). Based on this estimate, we calculated that an increase in the biomass of infected oysters to $108 \mathrm{~g}$ would increase the relative risk of mortality by 3.9 times in exposed animals. However, during this period, the biomass of infected oysters did not influence the risk of disease mortality in challenged oysters.

During the next period ( 7 to $19 \mathrm{~d}$ ), this parameter estimate did not change in exposed oysters, but it increased markedly in challenged oysters (odds ratio $=10.2 ;$ Table 6 ). Therefore, the odds of mortality increased with the biomass of infected animals in both challenged and exposed oysters, but not at the same magnitude, nor at the same time.

Final survival decreased gradually with increasing biomass of infected animals from 91.2 to $74.6 \%$ in exposed oysters, and from 98.6 to $89.4 \%$ in challenged oysters (Fig. 5C,D). Mortalities were low in this experiment compared to the previous ones, likely reflecting that this experiment was conducted at the end of the infection period.

\section{DISCUSSION}

\section{Rearing history of oyster seed: natural spatfall vs. nursery}

Our results (Expt A) showed that 31/51 batches of oyster seed collected from the wild when seawater temperature was $<14^{\circ} \mathrm{C}$ exhibited significant mortality under laboratory conditions at $21^{\circ} \mathrm{C}$, compared to only $1 / 32$ batches for animals sampled from a nursery. Therefore, the odds of mortality in wild oysters were 27 times higher than that of nursery animals. These results agree well with the fact that wild oyster seed is more exposed to disease risk in the field than those in nurseries, where they are likely to be protected from pathogens by means of prophylactic methods (Whittington et al. 2015).

We also observed that OsHV-1 $\mu$ Var occurred at high prevalence in the wild oysters. They were presumably infected in spatfall collection sites when the seawater temperature was between 16 and $24^{\circ} \mathrm{C}$ (Pernet et al. 2012, 2014b, Dégremont 2013, Petton et al. 2013, Clegg et al. 2014). OsHV-1, as with other members of the Herpesviridae family, probably persists during the winter in its host after primary infection without inducing signs of disease or mortality (Arzul et al. 2002, Dundon et al. 2011, Dégremont et al. 2013).

Our results suggest that OsHV-1 is maintained in wild oysters in most French farming areas. As a result, it is most unlikely that OsHV-1 could be wiped out in sites where stocks of oysters are selfrecruiting. However, in areas where oysters do not recruit, either due to low temperature or hydrodynamics, OsHV-1 could be cleared by ceasing restocking until the population dies off (Murray et al. 2012). In areas where OsHV-1 has not yet been detected, the movement of wild oysters from selfrecruiting sites presents a high risk of disease transmission and mortality, compared to hatchery- 

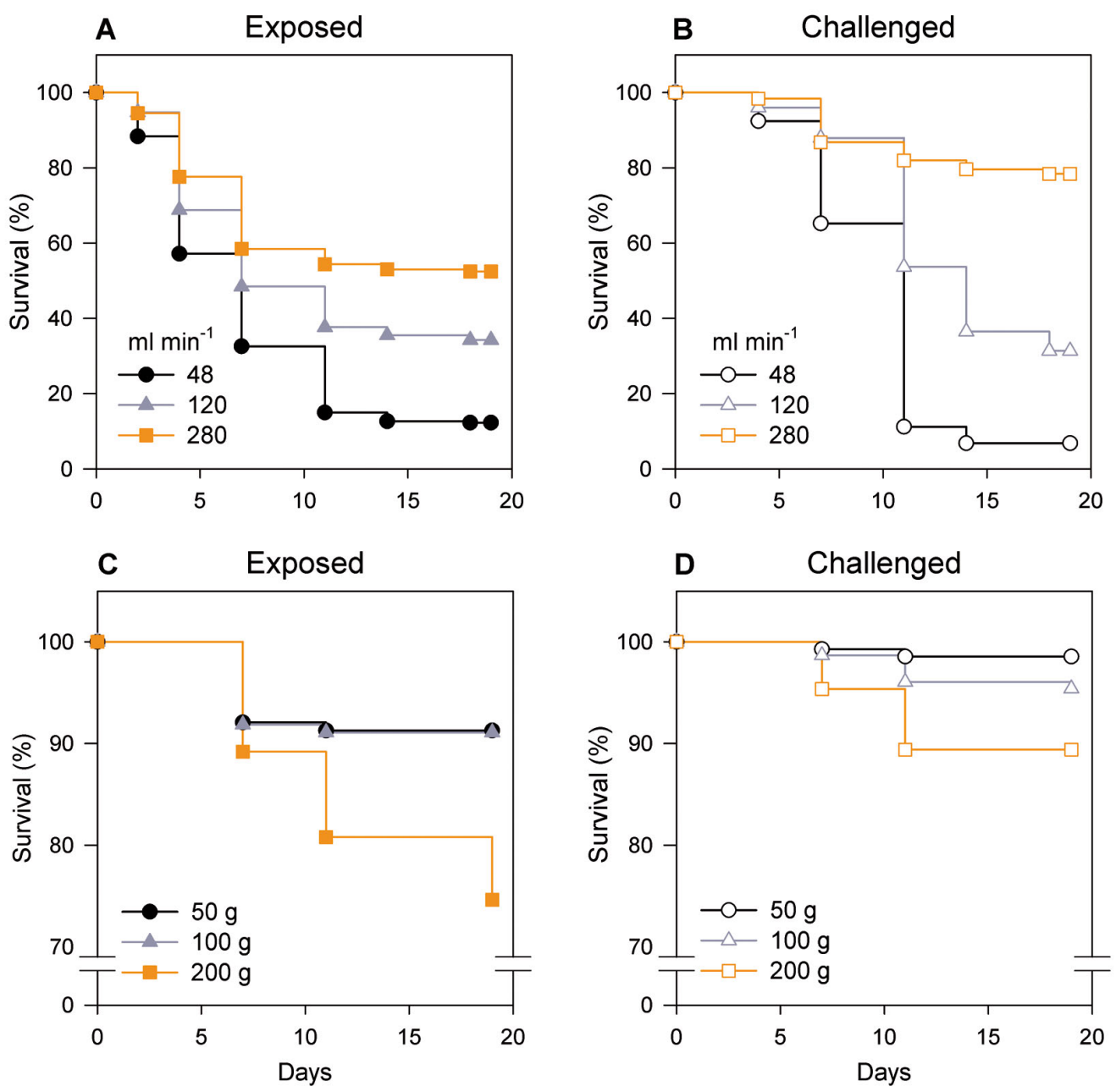

Fig. 5. Expt D. Survival of Pacific oysters Crassostrea gigas (A,C) exposed to field conditios in the Bay of Brest or (B,D) laboratory challenged (naïve oysters placed in cohabitation with exposed animals) as a function of time. Exposed and naïve oysters were placed in cohabitation at 3 different water renewal rates $\left(48,120\right.$ and $280 \mathrm{ml} \mathrm{min}^{-1}$; $\left.\mathrm{A}, \mathrm{B}\right)$ or with 3 different biomasses of infected animals $(50,100$ and $200 \mathrm{~g} ; \mathrm{C}, \mathrm{D})$

Table 6. Expt D. Odds of disease mortality as a function of water renewal (48, 120 and $280 \mathrm{ml} \mathrm{min}{ }^{-1}$ ) and biomass of infected oysters $(50,100$ and $200 \mathrm{~g}$ tank $^{-1}$ ) in exposed and challenged oysters for each time interval ( 0 to 7 and 7 to $19 \mathrm{~d}$ ). Custom hazard ratios were produced by means of polynomial (linear) exponentiated contrasts. The table also contains the standard error (SE) of the hazard ratio estimate and the confidence interval (CI) on the hazard ratio, the Wald $\chi^{2}$ statistic and the resulting $\mathrm{p}$-value

\begin{tabular}{|lccccr|}
\hline Variable & Odds ratio & SE & $95 \%$ CI & Wald $\chi^{2}$ & p \\
\hline Water renewal (linear) & & & & & \\
Exposed 0-7 d & 0.598 & 0.046 & $0.515-0.695$ & 44.9 & $<0.001$ \\
Challenged 0-7 d & 0.532 & 0.103 & $0.364-0.777$ & 10.6 & 0.001 \\
Exposed 7-19 d & 0.208 & 0.063 & $0.115-0.375$ & 27.2 & $<0.001$ \\
Challenged 7-19 d & 0.096 & 0.025 & $0.057-0.161$ & 79.4 & $<0.001$ \\
Biomass (linear) & & & & & \\
Exposed 0-7 d & 3.875 & 1.663 & $1.671-8.987$ & 10.0 & 0.002 \\
Challenged 0-7 d & 1.28 & 0.168 & $0.989-1.656$ & 3.5 & 0.061 \\
Exposed 7-19 d & 4.262 & 1.939 & $1.748-10.394$ & 10.2 & 0.001 \\
Challenged 7-19 d & 10.275 & 4.92 & $4.020-26.264$ & 23.7 & $<0.001$ \\
\hline
\end{tabular}

propagated seed and subsequent deployment in the field. Indeed, oysters collected from nurseries did not exhibit mortality at $21^{\circ} \mathrm{C}$ under laboratory conditions, and OsHV-1 DNA was not detected before or during the thermal challenge. Therefore, it appears that movement of wild oysters strongly increases the risk of disease transmission and mortality compared to that of nursery animals, which are generally safe before their deployment to the field until the temperature reaches $\sim 15^{\circ} \mathrm{C}$, a threshold temperature at which disease transmission occurs (see next section). 


\section{Threshold temperature and onset of oyster mortality}

The present study (Expts B and C) confirms that Pacific oyster mortality starts during spring when the seawater temperature reaches $\sim 16^{\circ} \mathrm{C}$, and coincides with detection of high quantities of OsHV-1 $\mu$ Var DNA in oyster tissues (EFSA 2010, Segarra et al. 2010, Oden et al. 2011, Peeler et al. 2012, Pernet et al. 2012, 2014a, Dégremont et al. 2013, Petton et al. 2013, Clegg et al. 2014). It is, however, noteworthy that in Aber Benoît the onset of mortality occurred between 17 May and 15 June 2011, while average maximum daily seawater temperature was only $15.0^{\circ} \mathrm{C}$. However during this time interval, seawater temperature had occasionally exceeded $16^{\circ} \mathrm{C}$ (the maximum seawater temperature recorded was $18.1^{\circ} \mathrm{C}$ on 15 June). Although the average daily seawater temperature of $16^{\circ} \mathrm{C}$ is a threshold above which disease transmission is optimal and mortalities occur, daily temperature variability likely enhances the risk of disease mortality, as previously shown in the withering syndrome in black abalone (Ben-Horin et al. 2013).

In contrast to Europe, OsHV-1 associated mortality of Pacific oysters in Australia occurs when seawater temperature is between 23 and $26^{\circ} \mathrm{C}$ (Jenkins et al. 2013, Paul-Pont et al. 2013, 2014). Therefore, it seems that the temperature threshold at which disease mortality occurs is not the same worldwide. The link between seawater temperature and the onset of mortality may be indirect, and it could involve other environmental, physiological or genetic factors that vary between Europe and Australia.

\section{Seasonality of disease transmission: consequences for management of oyster movements}

Healthy oysters deployed to the field between 22 November and 20 April when seawater temperature was $<14.7^{\circ} \mathrm{C}$ exhibited no mortality in the laboratory at $21^{\circ} \mathrm{C}$, and OsHV-1 DNA was not detected in their tissues, suggesting they were not infected by the virus (Expt A). Compared with previous studies which reported that no abnormal mortality occurred and OsHV-1 DNA was not detected in oyster tissues collected in the field during the winter (Oden et al. 2011, Pernet et al. 2012, Dégremont 2013), we further suggest that OsHV-1 is not transmitted to healthy oysters during this period.

In contrast, oysters left in the field until 3 May 2011 exhibited significant mortalities in the laboratory at $21^{\circ} \mathrm{C}$ and OsHV-1 DNA was detected in their tissues, when mortality had not yet been recorded in the field. Therefore, the temperature elevation under laboratory conditions revealed that OsHV-1 was transmitted to oysters between 20 April and 3 May, while daily average seawater temperature was between 14.7 and $15.8^{\circ} \mathrm{C}$ (the average seawater temperature during this period being $15.3 \pm 0.3^{\circ} \mathrm{C}$ ). Transmission of OsHV-1 under laboratory conditions from diseased to naïve oysters has been reported at temperature as low as $13.4^{\circ} \mathrm{C}$ and has led to significant mortalities in naïve animals at $14.4^{\circ} \mathrm{C}$ (Petton et al. 2013). Similarly in the Mediterranean Thau lagoon, OsHV-1 DNA was detected in sentinel oysters deployed at 33/104 locations when seawater temperature had just reached $16.0^{\circ} \mathrm{C}$, indicating that disease transmission had occurred earlier, when seawater temperature was $<16^{\circ} \mathrm{C}$ (Pernet et al. 2014b).

Oysters deployed in the field in spring (31 May) and summer (4 July) while seawater temperature was between 16 and $20^{\circ} \mathrm{C}$ showed significant mortalities in the laboratory at $21^{\circ} \mathrm{C}$, concomitant with the detection of OsHV-1 DNA. This result corroborates that the optimal temperature range for disease transmission is between 16 and $22^{\circ} \mathrm{C}$ (Petton et al. 2013). Interestingly, survival of oysters in the laboratory at $21^{\circ} \mathrm{C}$ decreased with duration of field exposure in a manner similar to a dose-response relationship.

In France, oyster farming commonly involves the movement of large numbers of animals between rearing sites at successive steps in their production in order to optimize growth. These movements are likely to facilitate the spread of pathogens (EFSA 2010, Murray et al. 2012, Peeler et al. 2012, Murray 2013, Brenner et al. 2014). Our results show that the risk of infection of healthy oysters (in which OsHV-1 DNA was not detected and did not show any mortality after exposure at $21^{\circ} \mathrm{C}$ ) exposed to field conditions was low, as long as daily average seawater temperature was $<14.7^{\circ} \mathrm{C}$, suggesting that further movements of these animals represents a low risk of disease transmission and mortality. However, when seawater temperature was between 14.7 and $15.8^{\circ} \mathrm{C}$ $\left(\sim 15.3^{\circ} \mathrm{C}\right)$, OsHV-1 was transmitted to oysters. Therefore, movements of healthy oysters during the spring (when no abnormal mortality has yet occurred) still presents a risk of infection and transmission of the virus. Finally, when seawater temperature is $>16^{\circ} \mathrm{C}$ and mass mortalities have started, the risk of spreading OsHV-1 with oyster movements is high and increases with duration of exposure to field conditions where the virus is found. 


\section{Effects of age and size on disease susceptibility of oysters: consequences for seeding}

In our study (Expt C), survival of oysters at 2 rearing sites increased markedly with age (and size) during disease outbreak. Similarly, other studies have shown that resistance of oysters to OsHV-1 increased with age and size (Dégremont 2013), likely reflecting maturation of the immune system (Green et al. 2014). These authors suggested that the host's ontogeny influences the antiviral response in C. gigas. Alternatively, the higher cell replication rates of young animals could favour the replication of OsHV-1, as herpesviruses rely on the host's cell replication machinery (Lyman \& Enquist 2009).

The effect of age on the probability of mortality became progressively less important with time. This long-term effect may reflect that the cause of mortality had changed. For instance, we showed that the onset of mortality coincided with detection of OsHV1 DNA by qPCR, although no pathogen analysis was conducted following detection. In support of this hypothesis, significant mortality occurred during the cold months, which is not compatible with OsHV-1 infection (EFSA 2010, Oden et al. 2011, Pernet et al. 2012, Petton et al. 2013).

The effects of oyster age and size on disease susceptibility were confounded in previous studies (Pernet et al. 2012, Dégremont 2013, Clegg et al. 2014, Paul-Pont et al. 2014). In our study as well, older oysters (which are less susceptible than younger ones) were larger. However, shell lengths of live and dead oysters after the outbreak of the disease were similar, suggesting that there was no relationship between disease susceptibility and oyster size. Similarly, PaulPont et al. (2014) reported that the age of oysters was a significant determinant of disease mortality rate, but size was not significant after allowing for variation in age. For example, these authors reported that 3 to 9 mo old oysters exhibited 80 to $100 \%$ mortality regardless of shell length, which varied from 2 to 96 mm (Paul-Pont et al. 2014).

Although survival of oysters varied as function of the interaction between time $\times$ site $\times$ age, survival of oysters increased as they aged both in Aber Benoît and in the Bay of Brest, as previously reported at Marennes-Oléron Bay (Dégremont 2013). In contrast, in the Mediterranean Thau lagoon, oysters remained highly susceptible to pathogen-related mortality pressure during their first $2 \mathrm{yr}$ (Pernet et al. 2012). It is therefore possible that the age $\times$ site interaction affects mortality, as previously reported for the summer mortality syndrome (Dégremont et al. 2010b).
From a practical standpoint, our study has shown that the probability of mortality decreased with the age of oysters when facing the disease for the first time. Although the effect of age on odds of mortality became progressively less important with time, seeding older, healthy oysters led to higher overall survival. Therefore, it might be interesting to deploy oyster seed during the fall instead of the spring, so that animals are older and less susceptible when the disease occurs. This was shown for our healthy oysters, but may not be the case for asymptomatic carriers (as were $60 \%$ of our tested wild oyster batches; see Expt A).

\section{Effect of water renewal and infectious biomass: perspectives for spatial planning}

Under our controlled conditions, odds of disease mortality for oysters decreased markedly with water renewal and increased with the biomass of neighbouring infected animals, probably reflecting dilution and concentration effects respectively of viral particles in the seawater (Expt D). In the same way, survival of oysters cemented onto ropes, where circulation of water around each individual is enhanced and the density of susceptible hosts is lowered, was markedly higher (66\%) compared to that of animals maintained in Australian baskets (13\%), where the circulation of water around each individual and flushing rate was lower and the density of susceptible hosts was higher (Pernet et al. 2012).

Overall, these results corroborate that infectious disease dynamics are regulated by host population size and density, since larger and denser populations have increased contact between infectious and susceptible individuals (Anderson \& May 1979). In terrestrial animal production, herd size and animal density are major risk factors for disease transmission (see e.g. Humblet et al. 2009 for review). This is also the case in finfish aquaculture (Krkošek 2010), where increased numbers of infectious fish lead to increased pathogen concentration in the surrounding environment, which in turn enhances the risk of pathogen transmission (Murray 2009). Similarly, a combined epidemiological-hydrodynamic model demonstrated that the number of infections in salmon increases with farm size (biomass) (Salama \& Murray 2011).

The effects of water renewal and infectious biomass on disease transmission could explain the observed differences in oyster survival between and within farming sites. For instance, survival of oysters 
in the Thau lagoon, a semi-enclosed system in which the flushing rate is low (Fiandrino et al. 2003), is generally much lower than that observed along the Atlantic coast of France where animals are exposed to tidal regimes (Fleury \& Bedier 2013). Such differences are not likely linked to temperature, as this parameter mainly triggers the timing of mortality rather than final survival (Petton et al. 2013). Additionally, survival of oysters within the bivalve farming area of the Thau lagoon (where the density of susceptible hosts is the highest) is much lower than outside it (Pernet et al. 2014b).

Consequently, spatial planning of oyster farming should take into account the hydrodynamic regime and biomass of the oysters, not only from a growth or a trophic perspective as is currently the case (Cranford et al. 2012), but also from an epidemiological viewpoint. Currently, the majority of oyster leases are concentrated in sheltered inshore areas where tidal currents are relatively low, which are favourable conditions for disease transmission and mortality. Due to space constraints, bivalve farms may move further offshore in higher tidal areas in order to allow the industry to expand. From an epidemiological perspective, offshore bivalve farming only makes sense if oysters are imported from areas where infection is not present.

\section{Thermal challenge of oysters: a complementary tool to OsHV-1 DNA detection by PCR}

In Expt A, we showed that detection of OsHV-1 DNA by real-time PCR in oysters sampled when seawater temperature was $<14^{\circ} \mathrm{C}$ was not predictive of mortality risk. Although individual analyses of a greater number of oysters should be carried out to definitely rule out presence of OsHV-1, this result suggests that OsHV-1 DNA is hardly detectable in oysters when the virus is latent during the winter. However, the risk of mortality was highly correlated with detection of OsHV-1 DNA when oysters were exposed at $21^{\circ} \mathrm{C}$. In the Thau lagoon, risk of oyster mortality was positively correlated with detection of OsHV-1 DNA in oysters while the seawater temperature was $16^{\circ} \mathrm{C}$, but the odds ratio was only 1.4 (Pernet et al. 2014b). It is likely that the relationship between mortality risk and detection of OsHV-1 DNA is stronger when sampling time and the outbreak of disease are closer together, so that expression and detection of OsHV-1 can increase.

The lack of sensitivity of the OsHV-1 DNA PCR assay for detecting latent infection or asymptomatic carriers of the disease could become a limiting factor for developing proper disease management procedures. Indeed, improved diagnostic methods must be developed (EFSA 2010). Here, we provide evidence that thermal elevation of oysters to $21^{\circ} \mathrm{C}$ allows detection of asymptomatic carriers of OsHV-1. Our thermal challenge can be used for characterising the health status of oysters with regards to OsHV-1 complementary to PCR assays.

\section{CONCLUSIONS}

The present study provides evidence that the early rearing history, timing and duration of exposure to the disease in the field, age of oysters and water renewal and biomass of infected animals are important risk factors for OsHV-1 $\mu$ Var transmission and related mortalities in Crassostrea gigas. Although some of these parameters were tested only under laboratory conditions, they are likely to have important implications for disease management in oyster farming systems. For instance, our thermal challenge can be used for characterising the health status of oysters with regards to OsHV-1 in conjunction with PCR assays. If the tested oysters show no mortality during the challenge and OsHV-1 DNA is not detected in oyster tissues, they can be qualified as 'healthy' and could be moved with a low risk of OsHV-1 transmission to other stocks. Additionally, increasing the age at deployment in the field will significantly increase oyster survival when OsHV-1 outbreaks occur (i.e. at seawater temperature $>16^{\circ} \mathrm{C}$ ). Finally, high hydrodynamics (flushing rate) and low biomass of infected animals in the environment will contribute to increased survival. If the tested oysters exhibit significant mortality associated with OsHV-1 during the challenge, they will potentially transmit the disease to neighbouring stocks when the seawater temperature reaches $\sim 15^{\circ} \mathrm{C}$, in a way similar to what we observed in Expt B. Infected animals will likely die when seawater temperature reaches $16^{\circ} \mathrm{C}$ in the field. Similar to healthy oysters, high hydrodynamic rates and low biomass of infected animals will mitigate mortality within the population. Although all tested parameters exerted a significant influence on the survival of oysters, their effects can be masked by the high infection pressure which currently occurs in most farming areas. For instance, $60 \%$ of natural seed batches tested in our study were infected by OsHV-1, suggesting that these oysters are likely to contribute to the global high infection pressure. Including the parameters explored in our study into 
disease management scenarios may help to reduce the infection pressure of OsHV-1 in oyster farming systems.

Acknowledgements. The authors thank the Ifremer staff involved in oyster production at Argenton, the shellfish networks (Resco and Velyger) for providing temperature measurements, and Gaétan Daigle, Département de mathématique et statistique, Université Laval, Québec for advice with statistical analyses. This work was partly supported by Ifremer (project 'Surmortalité' 2010-11), the GIGASSAT project funded by ANR-AGROBIOSPHERE N ANR-12-AGRO0001-01 and the French Ministry of Food, Agriculture and Fisheries (Convention DPMA 2014 - Ifremer).

\section{LITERATURE CITED}

Anderson RM, May RM (1979) Population biology of infectious diseases: part I. Nature 280:361-367

Anderson JA, Senthilselvan A (1982) A two-step regression model for hazard functions. J R Stat Soc Ser C Appl Stat 31:44-51

Arzul I, Renault T, Thébault A, Gérard A (2002) Detection of oyster herpesvirus DNA and proteins in asymptomatic Crassostrea gigas adults. Virus Res 84:151-160

Ben-Horin T, Lenihan HS, Lafferty KD (2013) Variable intertidal temperature explains why disease endangers black abalone. Ecology 94:161-168

Bingham P, Brangenberg N, Williams R, van Andel M (2013) Investigation into the first diagnosis of ostreid herpesvirus type 1 in Pacific oysters. Surveillance 40:20-24

Brenner M, Fraser D, Van Nieuwenhove K, O'Beirn F and others (2014) Bivalve aquaculture transfers in Atlantic Europe. Part B: environmental impacts of transfer activities. Ocean Coast Manage 89:139-146

> Clegg TA, Morrissey T, Geoghegan F, Martin SW, Lyons K, Ashe S, More SJ (2014) Risk factors associated with increased mortality of farmed Pacific oysters in Ireland during 2011. Prev Vet Med 113:257-267

Cox DR (1972) Regression models and life tables. J R Stat Soc Series B Stat Methodol 20:187-220

Cranford PJ, Kamermans P, Krause G, Mazurié J and others (2012) An ecosystem-based approach and management framework for the integrated evaluation of bivalve aquaculture impacts. Aquacult Environ Interact 2:193-213

> Dégremont L (2011) Evidence of herpesvirus (OsHV-1) resistance in juvenile Crassostrea gigas selected for high resistance to the summer mortality phenomenon. Aquaculture 317:94-98

> Dégremont L (2013) Size and genotype affect resistance to mortality caused by OsHV-1 in Crassostrea gigas. Aquaculture 416-417:129-134

> Dégremont L, Bédier E, Boudry P (2010a) Summer mortality of hatchery-produced Pacific oyster spat (Crassostrea gigas). II. Response to selection for survival and its influence on growth and yield. Aquaculture 299:21-29

> Dégremont L, Boudry P, Ropert M, Samain JF, Bédier E, Soletchnik P (2010b) Effects of age and environment on survival of summer mortality by two selected groups of the Pacific oyster Crassostrea gigas. Aquaculture 299: $44-50$

> Dégremont L, Guyader T, Tourbiez D, Pépin JF (2013) Is horizontal transmission of the ostreid herpesvirus OsHV-1 in
Crassostrea gigas affected by unselected or selected survival status in adults to juveniles? Aquaculture 408-409: 51-57

> Dundon WG, Arzul I, Omnes E, Robert M and others (2011) Detection of type 1 ostreid herpes variant (OsHV-1 $\mu v a r)$ with no associated mortality in French-origin Pacific cupped oyster Crassostrea gigas farmed in Italy. Aquaculture 314:49-52

EFSA (European Food Safety Authority) (2010) Scientific opinion on the increased mortality events in Pacific oysters, Crassostrea gigas. EFSA J 8:1894, doi:10.2903/ j.efsa.2010.1894

> Fiandrino A, Martin Y, Got P, Bonnefont JL, Troussellier M (2003) Bacterial contamination of Mediterranean coastal seawater as affected by riverine inputs: simulation approach applied to a shellfish breeding area (Thau lagoon, France). Water Res 37:1711-1722

Fleury E, Bedier E (2013) RESCO-RESeau d'Observations Conchylicoles: Campagne 2012. Ifremer

> Goulletquer P, Le Moine O (2002) Shellfish farming and coastal zone management (CZM) development in the Marennes-Oléron Bay and Charentais Sounds (Charente Maritime, France): a review of recent developments. Aquacult Int 10:507-525

Green TJ, Montagnani C, Benkendorff K, Robinson N, Speck P (2014) Ontogeny and water temperature influences the antiviral response of the Pacific oyster, Crassostrea gigas. Fish Shellfish Immunol 36:151-157

Grizel H, Heral M (1991) Introduction into France of the Japanese oyster (Crassostrea gigas). ICES J Mar Sci 47: 399-403

Hess KR (1995) Graphical methods for assessing violations of the proportional hazards assumption in Cox regression. Stat Med 14:1707-1723

> Humblet MF, Boschiroli ML, Saegerman C (2009) Classification of worldwide bovine tuberculosis risk factors in cattle: a stratified approach. Vet Res 40:50, doi:10.1051/ vetres/2009033

Jenkins C, Hick P, Gabor M, Spiers Z and others (2013) Identification and characterisation of an ostreid herpesvirus-1 microvariant (OsHV-1 $\mu$-var) in Crassostrea gigas (Pacific oysters) in Australia. Dis Aquat Org 105:109-126

- Kaplan EL, Meier P (1958) Nonparametric estimation from incomplete observations. J Am Stat Assoc 53:457-481

> Krkošek M (2010) Host density thresholds and disease control for fisheries and aquaculture. Aquacult Environ Interact 1:21-32

Lee ET, Wang JW (2013) Statistical methods for survival data analysis. John Wiley \& Sons, Hoboken, NJ

> Lin DY, Wei LJ, Ying Z (1993) Checking the Cox model with cumulative sums of martingale-based residuals. Biometrika 80:557-572

> Lyman MG, Enquist LW (2009) Herpesvirus interactions with the host cytoskeleton. J Virol 83:2058-2066

- Martenot C, Oden E, Travaille E, Malas JP, Houssin M (2011) Detection of different variants of ostreid herpesvirus 1 in the Pacific oyster, Crassostrea gigas between 2008 and 2010. Virus Res 160:25-31

Murray AG (2009) Using simple models to review the application and implications of different approaches used to simulate transmission of pathogens among aquatic animals. Prev Vet Med 88:167-177

> Murray AG (2013) Epidemiology of the spread of viral diseases under aquaculture. Curr Opin Virol 3:74-78

Murray AG, Marcos-Lopez M, Collet B, Munro LA (2012) A 
review of the risk posed to Scottish mollusc aquaculture from Bonamia, Marteilia and oyster herpesvirus. Aquaculture 370-371:7-13

Oden E, Martenot C, Berthaux M, Travaillé E, Malas JP, Houssin M (2011) Quantification of ostreid herpesvirus 1 (OsHV-1) in Crassostrea gigas by real-time PCR: determination of a viral load threshold to prevent summer mortalities. Aquaculture 317:27-31

Paul-Pont I, Dhand NK, Whittington RJ (2013) Influence of husbandry practices on OsHV-1 associated mortality of Pacific oysters Crassostrea gigas. Aquaculture 412-413: 202-214

Paul-Pont I, Evans O, Dhand NK, Rubio A, Coad P, Whittington RJ (2014) Descriptive epidemiology of mass mortality due to Ostreid herpesvirus-1 (OsHV-1) in commercially farmed Pacific oysters (Crassostrea gigas) in the Hawkesbury River estuary, Australia. Aquaculture 422-423: 146-159

Peeler EJ, Reese RA, Cheslett DL, Geoghegan F, Power A, Thrush MA (2012) Investigation of mortality in Pacific oysters associated with Ostreid herpesvirus-1 $\mu$ Var in the Republic of Ireland in 2009. Prev Vet Med 105:136-143

Pepin JF, Riou A, Renault T (2008) Rapid and sensitive detection of ostreid herpesvirus 1 in oyster samples by real-time PCR. J Virol Methods 149:269-276

Pernet F, Barret J, Le Gall P, Corporeau C and others (2012) Mass mortalities of Pacific oysters Crassostrea gigas reflect infectious diseases and vary with farming practices in the Mediterranean Thau lagoon, France. Aquacult Environ Interact 2:215-237

Pernet F, Lagarde F, Le Gall P, D'Orbcastel ER (2014a) Associations between farming practices and disease mortality of Pacific oyster Crassostrea gigas in a Mediterranean lagoon. Aquacult Environ Interact 5:99-106

Pernet F, Lagarde F, Jeannée N, Daigle G and others (2014b) Spatial and temporal dynamics of mass mortalities in Pacific oyster is influenced by energetic reserves and food quality. PLoS ONE 9:e88469

Petton B, Pernet F, Robert R, Boudry P (2013) Temperature influence on pathogen transmission and subsequent mortalities in juvenile Pacific oysters Crassostrea gigas. Aquacult Environ Interact 3:257-273

Pfeiffer DU (2010) Veterinary epidemiology: an introduction. John Wiley \& Sons, Hoboken, NJ

Renault T (2011) A review of mortality outbreaks in the

Editorial responsibility: Marianne Holmer, Odense, Denmark
Pacific oyster, Crassostrea gigas, reported since 2008 in various European Union Member States and the related implementation of Council Directive 2008/88/EC. Bulletin OIE 4:51-52

Renault T, Moreau P, Faury N, Pepin JF, Segarra A, Webb S (2012) Analysis of clinical ostreid herpesvirus 1 (Malacoherpesviridae) specimens by sequencing amplified fragments from three virus genome areas. J Virol 86: 5942-5947

Rico-Villa B, Woerther P, Mingant C, Lepiver D, Pouvreau S, Hamon M, Robert R (2008) A flow-through rearing system for ecophysiological studies of Pacific oyster Crassostrea gigas larvae. Aquaculture 282:54-60

Rico-Villa B, Pouvreau S, Robert R (2009) Influence of food density and temperature on ingestion, growth and settlement of Pacific oyster larvae, Crassostrea gigas. Aquaculture 287:395-401

Salama NKG, Murray AG (2011) Farm size as a factor in hydrodynamic transmission of pathogens in aquaculture fish production. Aquacult Environ Interact 2:61-74

Schikorski D, Faury N, Pepin JF, Saulnier D, Tourbiez D, Renault T (2011a) Experimental ostreid herpesvirus 1 infection of the Pacific oyster Crassostrea gigas: kinetics of virus DNA detection by q-PCR in seawater and in oyster samples. Virus Res 155:28-34

Schikorski D, Renault T, Saulnier D, Faury N, Moreau P, Pépin JF (2011b) Experimental infection of Pacific oyster Crassostrea gigas spat by ostreid herpesvirus 1: demonstration of oyster spat susceptibility. Vet Res 42:27, doi: 10.1186/1297-9716-42-27

Segarra A, Pepin JF, Arzul I, Morga B, Faury N, Renault T (2010) Detection and description of a particular ostreid herpesvirus 1 genotype associated with massive mortality outbreaks of Pacific oysters, Crassostrea gigas, in France in 2008. Virus Res 153:92-99

Webb SC, Fidler A, Renault T (2007) Primers for PCR-based detection of ostreid herpes virus-1 (OsHV-1): application in a survey of New Zealand molluscs. Aquaculture 272: 126-139

Whittington RJ, Hick PM, Evans O, Rubio A, Alford B, Dhand N, Paul-Pont I (2015) Protection of Pacific oyster (Crassostrea gigas) spat from mortality due to ostreid herpesvirus 1 (OsHV-1 $\mu$ Var) using simple treatments of incoming seawater in land-based upwellers. Aquaculture 437:10-20

Submitted: July 28, 2014; Accepted: January 9, 2015

Proofs received from author(s): February 27, 2015 